\title{
Klasifikasi Fase Retinopati Diabetes Menggunakan Backpropagation Neural Network
}

\author{
Rocky Yefrenes Dillak*1, Agus Harjoko ${ }^{2}$ \\ ${ }^{1}$ Mahasiswa Pascasarjana Jurusan Ilmu Komputer dan Elektronika, FMIPA UGM, Yogyakarta \\ ${ }^{2}$ Jurusan Ilmu Komputer dan Elektronika, FMIPA UGM, Yogyakarta \\ e-mail: *1rocky_dillak@yahoo.com, ${ }^{2}$ aharjoko@ugm.ac.id
}

\begin{abstract}
Abstrak
Retinopati diabetes (DR) merupakan salah satu komplikasi pada retina yang disebabkan oleh penyakit diabetes. Tingkat keparahan DR dibagi atas empat kelas yakni: normal, non-proliferative diabetic retinopathy (NPDR), proliferative diabetic retinopathy $(P D R)$, dan macular edema (ME). Penelitian ini bertujuan mengembangkan suatu metode yang dapat digunakan untuk melakukan klasifikasi terhadap fase DR. Data yang digunakan sebanyak 97 citra yang fitur - fiturnya diekstrak menggunakan gray level cooccurence matrix (GLCM). Fitur ciri tersebut adalah maximum probability, correlation, contrast, energy, homogeneity, dan entropy. Fitur - fitur ini dilatih menggunakan jaringan syaraf tiruan backpropagation untuk dilakukan klasifikasi. Kinerja yang dihasilkan dari pendekatan ini adalah sensitivity $100 \%$, specificity $100 \%$ dan accuracy $97.73 \%$
\end{abstract}

Kata kunci-fase retinopati diabetes, GLCM, backpropagation neural network

\begin{abstract}
Diabetic retinopathy $(D R)$ is one of the complications on retina caused by diabetes. The aim of this studyis to develop a system that can be used for automatic mass screenings of diabetic retinopathy. Four classes are identified: normal retina, non-proliferative diabetic retinopathy (NPDR), proliferative diabetic retinopathy (PDR), and macular edema (ME). Ninenty-seven retinal fundus images in used in this study. Six different texture features such as maximum probability, correlation, contrast, energy, homogeneity, and entropy were extracted from the digital fundus images using gray level cooccurence matrix (GLCM). These features were fed into a backpropagation neural network classifier for automatic classification. The proposed approach is able to classify with sensitivity 100\%, specificity $100 \%$ and accuracy $97.73 \%$
\end{abstract}

Keywords - diabetic retinopathy stages, GLCM, backpropagation neural network

\section{PENDAHULUAN}

$\mathrm{R}$ etinopati Diabetes (DR) merupakan salah satu komplikasi penyakit diabetes. Komplikasi tersebut berupa kerusakan pada bagian retina mata yang akan berdampak langsung pada terganggunya penglihatan penderita dan apabila terlambat ditangani akan menyebabkan penderita mengalami kebutaan permanen.

Gejala yang ditunjukkan oleh penderita DR antara lain mikroneurisma, hemorrhages, hard exudates, soft exudates dan neovascularis. Gejala-gejala tersebut pada suatu intensitas tertentu dapat menjadi indikator fase (tingkat keparahan) retinopati diabetes. Secara umum fase tersebut dibagi dalam tiga fase, yaitu non-proliferative diabetic retinopathy (NPDR) proliferative diabetic retinopathy (PDR) serta macular edema (ME) [1]. 
Pemeriksaan medis terhadap penderita penyakit retinopati diabetes dilakukan dengan pengamatan secara langsung pada citra retina pasien yang diambil menggunakan kamera fundus. Kelemahan metode ini adalah lambatnya penanganan penyakit tersebut. Oleh karena itu, untuk mengatasi kelemahan tersebut dibutuhkan sistem pengolahan citra digital berbasis machine learning yang mampu memproses citra retina secara cepat dan akurat dalam mengklasifikasi fase DR untuk membantu dokter dalam menetapkan tindakan medis secara cepat dan tepat.

Permasalahan yang sering muncul dalam penelitian tentang anomaly detection pada citra digital menggunakan machine learning adalah kesulitan memisahkan antara wilayah yang merupakan anomali (abnormal) dan wilayah yang bukan merupakan anomali (normal). Turut dikomputasinya wilayah normal sebagai ciri suatu anomali citra akan menyebabkan berkurangnya keunikan suatu anomali sehingga akan berakibat pada rendahnya kemampuan sistem dalam membedakan anomali dan bukan anomali dalam suatu citra [2]. Hal ini dapat terjadi juga pada penelitian tentang DR dimana terdapat wilayah tertentu dalam citra retina yang sebaiknya dieliminasi karena tidak mengandung ciri (keunikan), dalam penelitiannya [3] mengatakan bahwa optic disc (OD) merupakan suatu wilayah dalam citra retina normal yang memiliki karakteristik yang mirip dengan ciri yang terdapat dalam kelainan exudate pada citra penyakit DR. Hal ini juga didukung oleh beberapa penelitian yang melakukan eliminasi OD sebelum deteksi gejala exudate menghasilkan akurasi lebih tinggi dibandingkan dengan akurasi tanpa eliminasi OD [4]. Berdasarkan uraian di atas maka OD semestinya merupakan wilayah yang dieliminasi dan tidak perlu dikomputasi pada saat klasifikasi DR karena dapat mempengaruhi akurasi klasifikasi.

Berdasarkan latar belakang tersebut di atas, penelitian ini akan mengkaji pengaruh eliminasi wilayah OD untuk mengklasifikasi fase DR dengan algoritma jaringan syaraf tiruan backpropagation.

\section{METODE PENELITIAN}

\section{1. Analisis Kebutuhan Sistem}

Sesuai dengan analisis kebutuhan system yang dilakukan maka sistem yang dibangun harus mampu melakukan beberapa hal berikut:

1. Membaca citra masukan.

2. Melakukan preprocessing terhadap citra masukan.

3. Mengeliminasi optic disc pada citra masukan..

4. Mengekstrak ciri citra masukan.

5. Melakukan training terhadap ciri yang telah diekstrak.

6. Menampilkan hasil klasifikasi terhadap suatu citra.

\subsection{Rancangan Arsitektur Sistem}

Peneliti mengusulkan arsitektur sistem seperti Gambar 1. Penjelasan pada sub-bab berikut memaparkan dengan lebih detail proses yang terjadi dalam setiap bagiannya

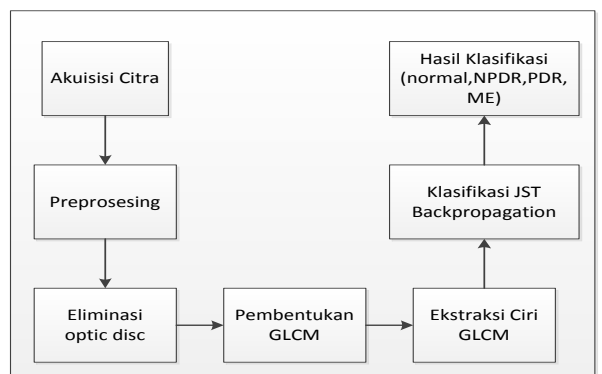

Gambar 1 Arsitektur sistem klasifikasi fase retinopati diabetes

IJCCS Vol. 7, No. 1, January 2013: $23-34$ 


\subsubsection{Preprosesing}

Tujuan utama dari preprosesing citra adalah untuk meningkatkan kualitas citra dimana citra yang dihasilkan dapat memberikan informasi yang lebih jelas bagi manusia sehingga memudahkan dalam melakukan interpretasi atas suatu citra [2]. Dalam penelitian ini digunakan dua teknik preprosesing sebagai berikut :

\section{Perenggangan kontras.}

Kontras suatu citra adalah distribusi piksel gelap dan terang. Citra keabuan dengan kontras yang rendah akan terlihat terlalu gelap, terlalu terang, atau terlalu abu-abu. berikut:

Pada peregangan kontras, setiap piksel pada citra $A$ ditransformasi menggunakan fungsi

$$
B(i, j)=\frac{A(i, j)-c}{(d-c)}(L-1)
$$

Dengan $B(i, j)$ dan $A(i, j)$ berturut-turut menyatakan piksel sesudah dan sebelum ditransformasi, c dan d menyatakan nilai minimum dan maksimum dari piksel citra masukan serta L menyatakan nilai grayscale maksimum.

\section{Filter median.}

Filter median adalah salah satu filter yang sangat baik dalam mereduksi noise berjenis salt \& pepper sehingga sangat sering digunakan dalam memperbaiki kualitas citra retina khususnya penelitian dibidang retinopati diabetes [5]. Filter median bekerja dengan mengganti nilai suatu piksel pada citra asal (pusat citra) dengan nilai median dari piksel citra asal tersebut berdasarkan suatu lingkungan tetangga (window) yang diformulasikan :

$$
\begin{aligned}
& f(x, y)=\operatorname{median}\{\mathrm{g}(\mathrm{s}, \mathrm{t})\} \\
& (s, t) \in S_{x, y}
\end{aligned}
$$

Dimana $S_{x, y}$ merupakan suatu window. Pada umumnya ukuran window $\left(\mathrm{S}_{\mathrm{x}, \mathrm{y}}\right)$ yang dipilih adalah bernilai ganjil. Jika $S_{x, y}$ adalah genap, nilai tengahnya diambil dari nilai ratarata dua buah piksel yang ditengah. Ukuran window yang biasa digunakan yaitu $3 \times 3,5 \times 5$ dan $7 \times 7$.

\subsubsection{Eliminasi optic disc}

Optic Disc (OD) atau pusat syaraf mata merupakan daerah pada mata tempat syaraf mata memasuki retina dan merupakan pertemuan seluruh syaraf mata [6]. Tahap - tahap eliminasi OD adalah thresholding, dilasi, invert dan perkalian citra sebagai berikut :

\section{Thresholding.}

Thresholding adalah proses mengubah citra berderajat keabuan menjadi citra biner atau hitam putih sehingga dapat diketahui daerah mana yang termasuk obyek dan background dari citra secara jelas. Untuk keperluan segmentasi OD maka digunakan metode thresholding global, menggunakan persamaan:

$$
g(x, y)=\left\{\begin{array}{lll}
1 & \text { if } & f(x, y)>T \\
0 & \text { if } & f(x, y) \leq T
\end{array}\right.
$$


2. Dilasi.

Operasi dilasi merupakan suatu operasi morfologi citra yang dilakukan untuk memperbesar ukuran segmen obyek dengan menambah lapisan disekeliling obyek. Operasi morfologi dilasi menggunakan dua buah input yaitu suatu citra dan suatu window yang disebut juga structuring element (SE). SE merupakan suatu matrik yang umumnya berukuran kecil yang digunakan untuk memperbesar citra input.

Pada citra biner, dilasi merupakan proses penggabungan titik-titik latar (0) menjadi bagian dari objek (1), berdasarkan structuring element yang digunakan. Bila suatu obyek (citra input) dinyatakan dengan $\mathrm{A}$ dan $\mathrm{SE}$ dinyatakan dengan $\mathrm{B}$ serta Bx menyatakan translasi B sedemikian sehingga pusat $\mathrm{B}$ terletak pada $\mathrm{x}$, maka operasi dilasi A dengan B dapat dinyatakan sebagai berikut :

$D(A, B)=A \oplus B=\left\{x: B_{x} \cap A \neq \varnothing\right\}$

dengan $\varnothing$ menyatakan himpunan kosong.

Proses dilasi dilakukan dengan membandingkan setiap pixel citra input dengan nilai pusat SE, dimana nilai pusat SE diletakan pada pixel citra input. Jika ada 1 pixel SE sama dengan nilai pixel citra input, maka nilai pixel citra input tersebut diganti dengan nilai 1 . Proses serupa dilanjutkan dengan menggerakkan SE pixel demi pixel pada citra input.

3. Invert.

Invert adalah proses pemetaan nilai pixel suatu citra (dalam hal ini citra biner) dimana nilai pixel hitam (0) akan dirubah menjadi putih (1) demikian juga sebaliknya.

4. Perkalian Citra.

Perkalian dua buah citra dapat dilakukan dengan persamaan :

$\mathrm{C}(\mathrm{x}, \mathrm{y})=\mathrm{A}(\mathrm{x}, \mathrm{y}) * \mathrm{~B}(\mathrm{x}, \mathrm{y})$

dimana

$\mathrm{C}=$ citra hasil hasil perkalian citra A dan citra B

$\mathrm{x}, \mathrm{y}=$ posisi pixel

\subsubsection{Pembentukan GLCM}

Penelitian ini mengggunakan GLCM multi arah (multiple) yang dibentuk menggunakan jarak 2 pixel tetangga $(\mathrm{d}=2)$. Jarak 2 pixel tetangga dipilih karena termasuk salah satu jarak ideal dalam membentuk GLCM [7]. Langkah - langkah membentuk multiple GLCM dalam penelitian ini sebagai berikut :

1. Tetapkan jarak pixel (d) yang dinginkan.

2. Hitung semua arah yang mungkin.

3. Bentuk GLCM untuk setiap arah (menggunakan langkah - langkah membentuk GLCM ).

4. Hitung semua ciri statistik untuk setiap arah yang terbentuk.

5. Hitung rata - rata (mean) dari setiap ciri pada semua arah yang terbentuk.

Jumlah arah yang terbentuk pada distance $\mathrm{d}=2$ adalah 16 , artinya terdapat 16 GLCM yang terbentuk $\left(\mathrm{M}_{1}\right.$ sampai $\left.\mathrm{M}_{16}\right)$.

IJCCS Vol. 7, No. 1, January 2013: $23-34$ 


\subsubsection{Ekstraksi ciri GLCM}

Setelah GLCM terbentuk pada suatu jarak dan arah tertentu, maka langkah selanjutnya adalah menghitung ciri statistik dari semua GLCM yang telah terbentuk berdasarkan jarak dan arah yang telah terbentuk. Enam elemen yang diusulkan oleh [7] adalah : (i) maximum probability, (ii) entropi, (iii) energy, (iv) korelasi, (v) kontras, dan (vi) homogenitas. Proses ektraksi ciri dilakukan dengan menghitung 6 ciri statistik dari setiap GLCM (16 GLCM) sebagai berikut :

1. Max Probability $=\max \left(p_{i j}\right)$

2. Entropi.

Entropi menunjukan ukuran ketidakteraturan distribusi intesitas suatu citra pada matriks co-coccurence. Persamaannya untuk menghitung entropi adalah:

$$
\text { Entopi }=-\sum_{i=1}^{k} \sum_{j=1}^{k} p_{i j} \log _{2} p_{i j}
$$

3. Energi.

Energi adalah fitur untuk mengukur konsentrasi pasangan intensitas pada matriks $\mathrm{co}$ occurance [8]. Nilai energi akan makin membesar bila pasangan piksel yang memenuhi syarat matriks intensitas co-occurance terkonsentrasi pada beberapa koordinat dan mengecil bila letaknya menyebar. yang digunakan untuk menghitung energi adalah :

$$
\text { Energi }=\sum_{i=1}^{k} \sum_{j=1}^{k} p_{i j}^{2}
$$

4. Korelasi.

Ciri ini menunjukan tingkat korelasi antar pixel dalam suatu citra. Persamaannya adalah :

$$
\sum_{i=1}^{k} \sum_{j=1}^{k} \frac{\left(\mathrm{i}-\mathrm{m}_{\mathrm{r}}\right)\left(j-m_{c}\right) p_{i j}}{\sigma_{r} \sigma_{c}}
$$

\section{Kontras}

Kontras adalah fitur yang digunakan untuk mengukur kekuatan perbedaan intensitas dalam citra [8]. Nilai kontras membesar jika variasi intensitas citra tinggi dan menurun bila variasi rendah. Persamaan yang digunakan untuk mengukur kontras suatu citra ditunjukkan pada persamaan di bawah ini :

$$
\text { Kontras }=\sum_{i=1}^{k} \sum_{j=1}^{k}(i-j)^{2} p_{i j}
$$

6. Homogenitas

Homogenitas digunakan untuk mengukur kehomogenan variasi intensitas citra [8]. Nilai homogenitas akan semakin membesar bila variasi intensitas dalam citra mengecil. Homogenitas dihitung dengan persamaan di bawah ini : 


$$
\sum_{i=1}^{k} \sum_{j=1}^{k} \frac{p_{i j}}{1+|i-j|}
$$

Untuk melakukan klasifikasi terhadap fase DR, maka hasil proses ektraksi ciri statistik selanjutnya akan dijadikan sebagai data masukan untuk dilatih dengan jaringan syaraf tiruan (JST) untuk mengenali pola inputan serta pasangan pola outputnya.

\subsubsection{Pelatihan jaringan syaraf tiruan backpropagation}

Proses pelatihan jaringan pada dasarnya merupakan proses penyesuaian bobot-bobot untuk masing - masing simpul antara lapisan input, lapisan tersembunyi, dan lapisan output. Penyesuaian bobot dilakukan secara terus-menerus sampai dicapai error yang paling minimum. Fungsi aktivasi yang digunakan adalah fungsi aktivasi tangent hyperbolic. Flowchart algoritma pelatihan JST backpropagation seperti pada Gambar 2.

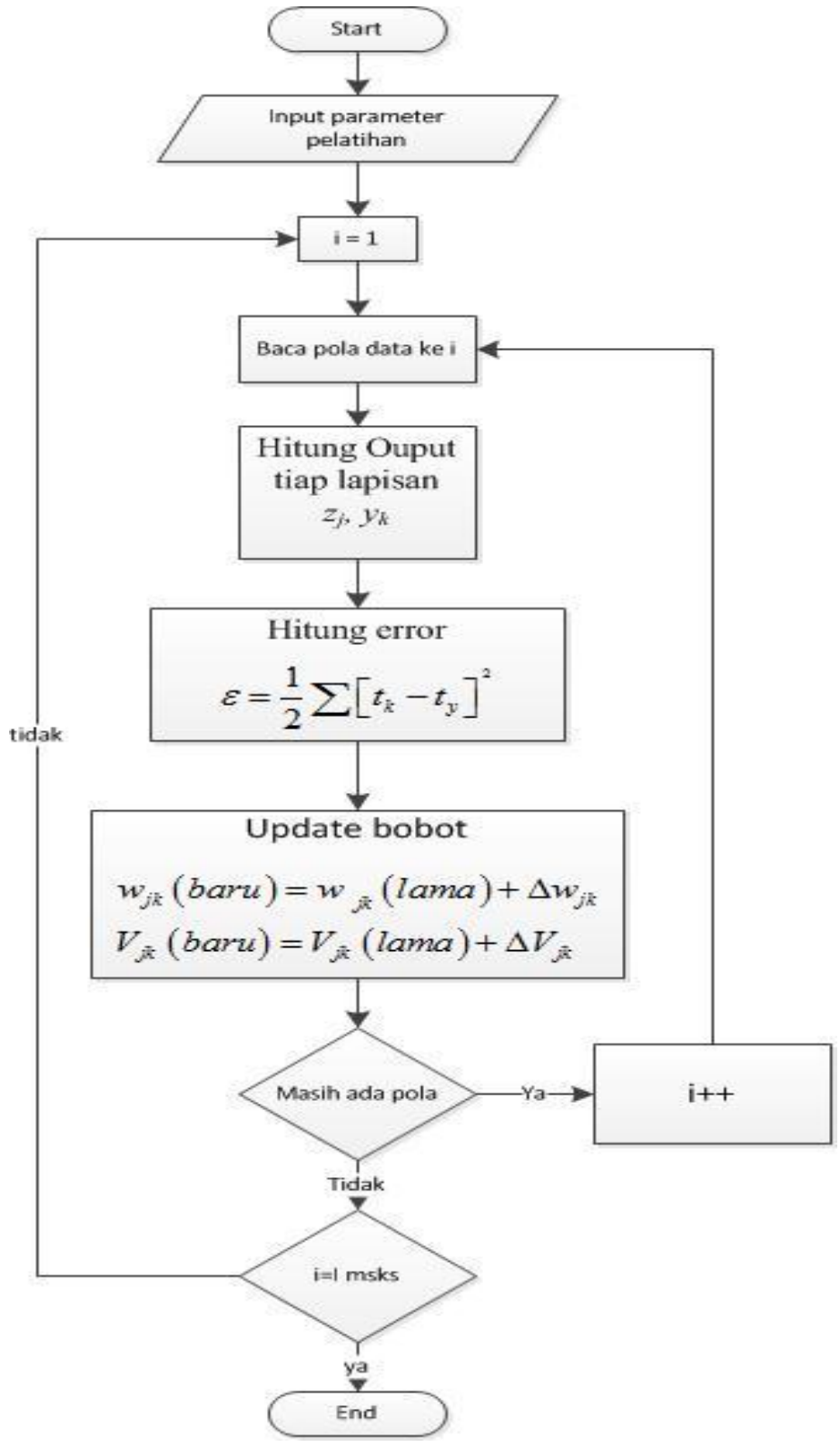

Gambar 2 Pelatihan JST

IJCCS Vol. 7, No. 1, January 2013 : $23-34$ 
Arsitektur JST yang digunakan dalam penelitian ini seperti pada Tabel 1.

Tabel 1 Arsitektur JST

\begin{tabular}{|c|c|c|}
\hline No & Arsitektur JST & Jumlah \\
\hline 1 & Input Neuron & 7 \\
\hline 2 & Hidden Layer & 1 layer (5-7 neuron) \\
\hline 3 & Output Neuron & 1 \\
\hline
\end{tabular}

- Data input yang digunakan sebagai pola dalam pelatihan JST sebanyak 6 buah yang terdiri atas 6 buah ciri statistik dan bias. Data inputan tersebut adalah :

$$
\begin{aligned}
& \text { x1 }=\text { maximum probability } \\
& \text { x2 }=\text { correlation } \\
& \text { x3 }=\text { contrast } \\
& \text { x4 }=\text { energy } \\
& \text { x5 = entropy } \\
& \text { x6 }=\text { hommogeneity } \\
& \text { x7 }=\text { bias }
\end{aligned}
$$

- Jumlah hidden layer : 1 lapisan tersembunyi, dengan jumlah neuron dalam lapisan tersembunyi divariasikan antara 5 - 7 neuron pada setiap hidden layer.

- Jumlah neuron dalam lapisan output sebanyak 1 neuron dengan target seperti pada Tabel 2.

Tabel 2 Target output JST

\begin{tabular}{|c|c|}
\hline Kelas & Target \\
\hline normal & 0 \\
\hline NPDR & 0.1 \\
\hline PDR & 0.2 \\
\hline ME & 0.3 \\
\hline
\end{tabular}

Arsitektur JST yang digunakan dalam penelitian ini seperti ditunjukkan pada Gambar 3.

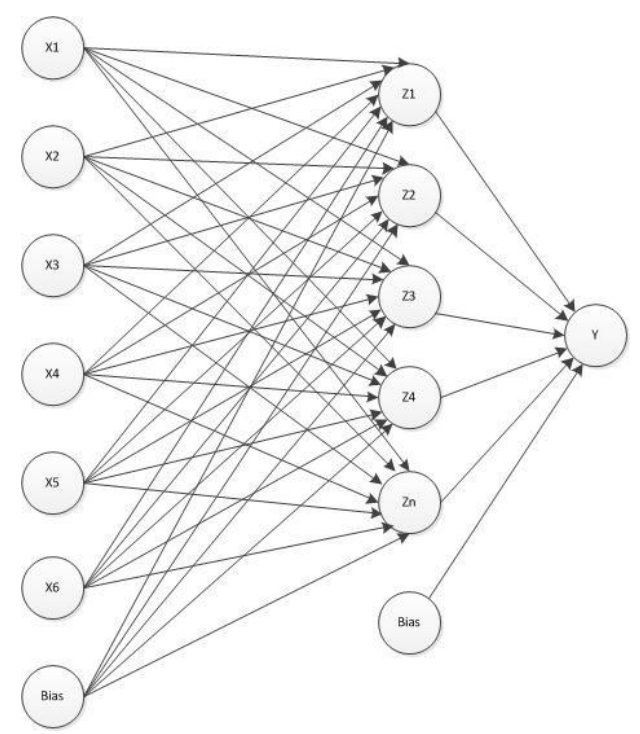

Gambar 3 Arsitektur JST 


\subsubsection{Pengujian jaringan syaraf tiruan backpropagation}

Setelah JST dilatih dengan sekumpulan pola maka tahap selanjutnya adalah melakukan pengujian terhadap kinerja dari JST sekaligus untuk mengukur kinerja dari sistem yang dibangun. Algoritma pengujian jaringan syaraf tiruan mengikuti flowchart seperti Gambar 4.

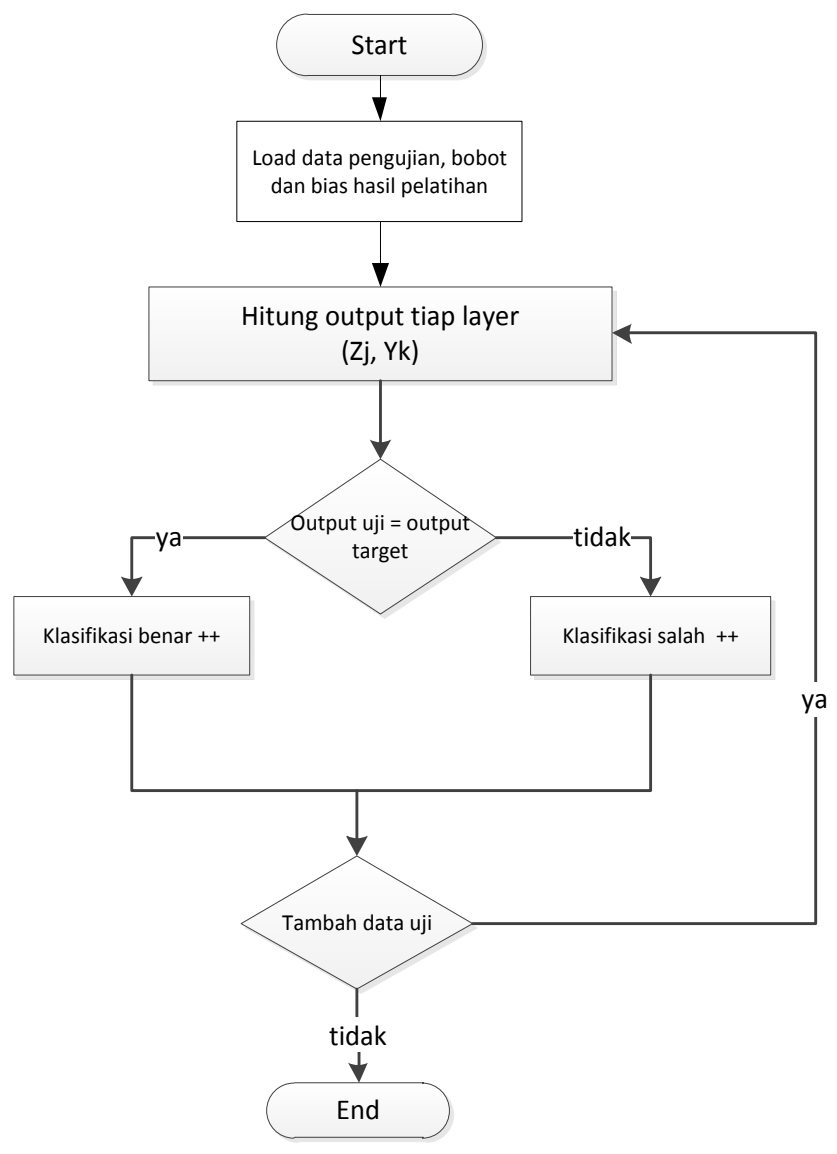

Gambar 4 Pengujian JST

\subsection{Implementasi}

Hasil visual implementasi dapat dilihat pada gambar form seperti ditunjukkan pada Gambar 5.

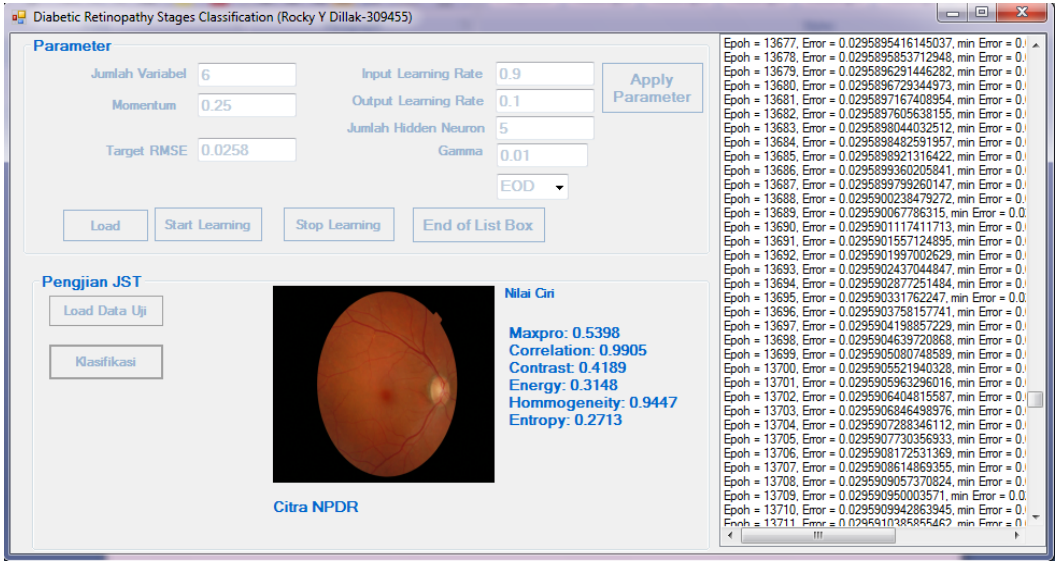

Gambar 5 Contoh tampilan form

IJCCS Vol. 7, No. 1, January 2013 : $23-34$ 


\section{HASIL DAN PEMBAHASAN}

Pada penelitian ini, pengujian dilakukan dengan melatih JST secara berulang-ulang untuk mendapatkan bobot-bobot jaringan yang optimal sehingga dapat digunakan untuk menyelesaikan permasalahan klasifikasi. Data yang digunakan dalam penelitian ini berjumlah 97 citra terbagi atas dua kelompok data yakni: (i) data pelatihan 62 citra dan (ii) data pengujian 35 citra. Data - data tersebut diekstrak menggunakan metode GLCM dengan jarak 2 pixel tetangga. Parameter JST yang digunakan dalam pengujian ini adalah sebagai berikut :

- $\quad$ Learning rate $(\alpha)=0.1$.

- $\quad$ Momentum $(\mu)=0.5$.

- Jumlah lapisan tersembunyi = 1 lapis.

- Jumlah neuron dalam lapis tersembunyi $=5$.

- $\quad$ Batas toleransi error $=0,001$.

\subsection{Pengujian Akurasi Kinerja JST Backpropagation}

Kinerja JST dalam mengklasifikasi fase citra retinopati diabetes diuji menggunakan data citra sebanyak tiga puluh lima buah citra yang telah diproses menggunakan dua pendekatan yakni pendekatan eliminasi optic disc dan pendekatan tanpa eliminasi optic disc. Hasil pengujian yang diperoleh digunakan untuk menghitung sensitivitas, spesivisitas, dan akurasi berdasarkan persamaan yang dilakukan pada penelitian sebelumnya [9].

Sensitivitas adalah persentasi abnormal hasil klasifikasi sistem sesuai klasifikasi dari kamera fundus. Spesivisitas adalah persentasi normal hasil klasifikais sistem sesuai klasifikasi dari kamera fundus. Semakin besar nilai persentase sensitivitas dan nilai persentese spesivisitas dari sistem maka semakin baik pula kinerja dari sistem tersebut.

Tabel 3 Hasil pengujian menggunakan pendekatan eliminasi OD

\begin{tabular}{|l|c|c|c|c|}
\hline Kelas & $\begin{array}{c}\text { Data } \\
\text { Pelatihan }\end{array}$ & $\begin{array}{c}\text { Data } \\
\text { Pengujian }\end{array}$ & $\begin{array}{c}\text { Klasifikasi } \\
\text { Benar }\end{array}$ & $\begin{array}{c}\text { Klasifikasi } \\
(\%)\end{array}$ \\
\hline Normal & 15 & 7 & 7 & $100.00 \%$ \\
\hline NPDR & 30 & 10 & 10 & $100.00 \%$ \\
\hline PDR & 8 & 11 & 10 & $90.91 \%$ \\
\hline ME & 9 & 7 & 7 & $100.00 \%$ \\
\hline
\end{tabular}

Berdasarkan hasil pengujian seperti pada Tabel 3 maka dapat dihitung sensitivitas, spesivisitas dan akurasi sistem berdasarkan persamaan yang dikemukakan [9].

Tabel 4 Sensitivity, specificity, and accuracy menggunakan pendekatan eliminasi OD

\begin{tabular}{|c|c|c|}
\hline Sensitivity in \% & $\begin{array}{c}\text { Specificity in } \\
\mathbf{\%}\end{array}$ & $\begin{array}{c}\text { Percentage of accuracy } \\
\mathbf{( \% )}\end{array}$ \\
\hline $100.00 \%$ & $100.00 \%$ & $97.73 \%$ \\
\hline
\end{tabular}

Hasil pengujian akurasi kinerja JST backpropagation menggunakan pendekatan eliminasi optic disc seperti ditunjukkan pada Tabel 3. Tabel 4 menunjukkan hasil sensitivity, specificity, dan percentage of accuracy, untuk empat fase citra retina menggunakan klasifikasi JST backpropagation. Hasil pengujian menunjukkan bahwa sistem dapat mendeteksi semua 
kelas Normal, NPDR, dan ME dengan sangat baik (akurasi mencapai 100\% untuk setiap kelas) dan hanya pada kelas PDR sistem tidak dapat mendeteksi keseluruhan citra pada kelas tersebut (akurasi mencapai 90.91\%). Sensitivitas dan specivisitas dari sistem mnecapai 100\%. Akurasi dari sistem yang diusulkan adalah $97.73 \%$.

Tabel 5 Hasil pengujian menggunakan pendekatan tanpa eliminais OD

\begin{tabular}{|l|c|c|c|c|}
\hline \multicolumn{1}{|c|}{ Kelas } & Data Pelatihan & Data Pengujian & Klasifikasi Benar & Klasifikasi (\%) \\
\hline Normal & 15 & 7 & 6 & $85.71 \%$ \\
\hline NPDR & 30 & 10 & 9 & $90.00 \%$ \\
\hline PDR & 8 & 11 & 8 & $72.73 \%$ \\
\hline ME & 9 & 7 & 3 & $42.86 \%$ \\
\hline
\end{tabular}

Tabel 6 Sensitivity, Specificity, and accuracy menggunakan pendekatan tanpa eliminasi OD

\begin{tabular}{|c|c|c|}
\hline Sensitivity in \% & $\begin{array}{c}\text { Specificity in } \\
\mathbf{\%}\end{array}$ & Percentage of accuracy (\%) \\
\hline $100.00 \%$ & $85.71 \%$ & $72.82 \%$ \\
\hline
\end{tabular}

Hasil pengujian akurasi kinerja JST backpropagation menggunakan pendekatan tanpa eliminasi optic disc ditunjukkan pada Tabel 3 Tabel 5 menunjukkan hasil sensitivity, specificity, dan percentage of accuracy, untuk empat fase citra retina menggunakan klasifikasi JST backpropagation. Hasil pengujian menunjukkan bahwa sistem tidak dapat mendeteksi kelas Normal, NPDR, PDR, dan ME dengan baik (akurasi < 100\%) pada fase Normal akurasi mencapai $85.71 \%$, fase NPDR akurasi mencapai $90.00 \%$, fase PDR akurasi mencapai $72.73 \%$, dan fase ME akurasi mencapai $42.86 \%$. Sensitivitas dari sistem mecapai $100 \%$ dan spesivisitas dari sistem mencapai $75 \%$. Akurasi dari sistem adalah $72.82 \%$.

\subsection{Perbandingan Akurasi Pendekatan Eliminasi OD dan Tanpa Eliminasi OD}

Berdasarkan hasil kajian di atas jelas terlihat bahwa klasifikasi fase retinopati diabetes menggunakan pendekatan eliminasi optic disc memberikan pengaruh yang sangat baik terhadap akurasi sistem (Tabel 4) dibandingkan dengan akurasi sistem klasifikasi fase retinopati diabetes menggunakan pendekatan tanpa eliminasi optic disc (Tabel 6). Sesuai nilai persentase sensitivitas dan spesivisitas dari kedua sistem tersebut (Tabel 4 dan Tabel 6), menunjukkan bahwa sistem yang menggunakan pendekatan eliminasi optic disc lebih baik dari sistem yang menggunakan pendekatan tanpa eliminasi optic disc. Klasifikasi menggunakan pendekatan eliminasi optic disc memberikan kontribusi berarti yakni meningkatnya akurasi klasifikasi sebesar $24.90 \%$ (Gambar 6).

IJCCS Vol. 7, No. 1, January 2013: $23-34$ 


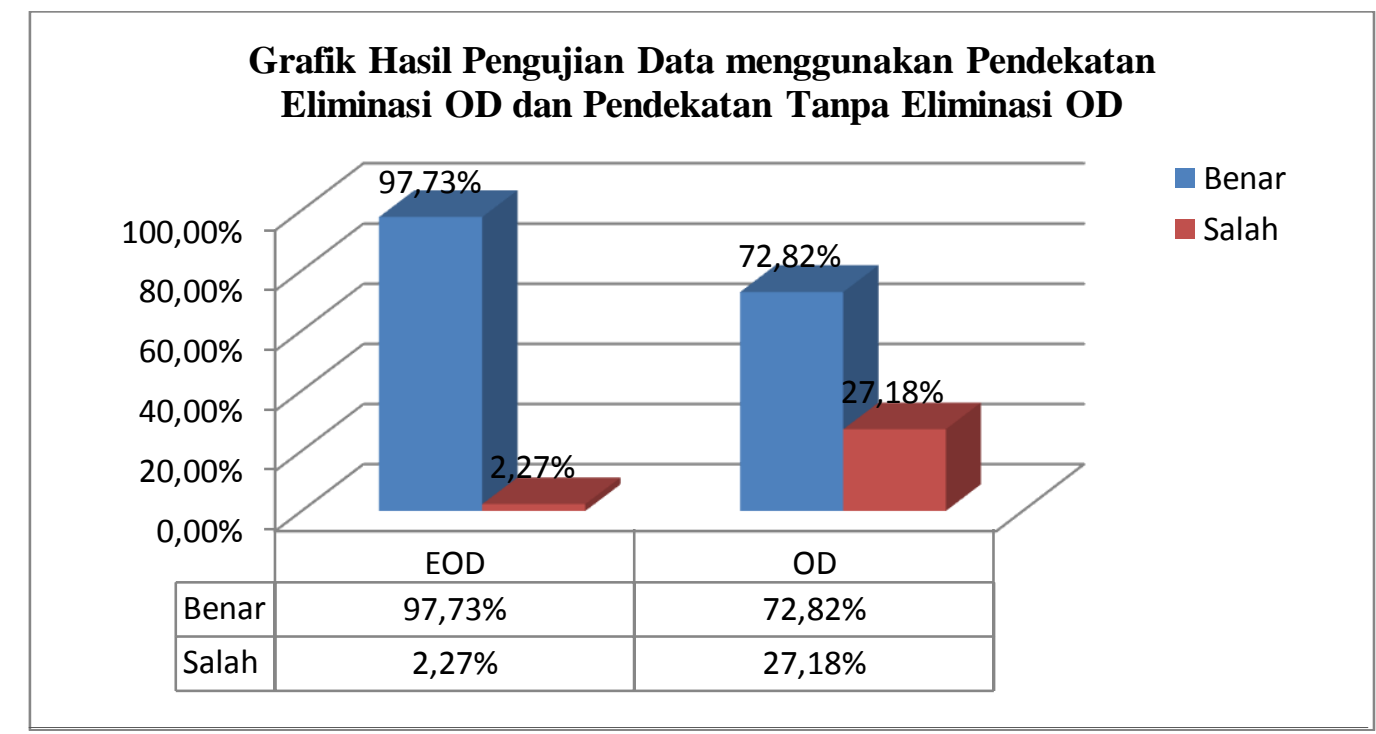

Gambar 6 Grafik perbandingan hasil pengujian menggunakan pendekatan eliminasi OD dan pendekatan tanpa eliminasi OD

\section{KESIMPULAN}

1. Pendekatan klasifikasi yang dilakukan dalam penelitian ini dapat melakukan klasifikasi dengan hasil akurasi $97.73 \%$

2. Perbandingan hasil akurasi klasifikasi pendekatan eliminasi optic disc adalah $97.73 \%$ lebih tinggi dibandingkan dengan pendekatan tanpa eliminasi optic disc (72.82\%)

\section{SARAN}

1. Untuk melihat kemampuan sistem dalam skala yang lebih besar maka dapat melakukan percobaan dengan data citra yang lebih banyak.

2. Post prosesing dapat diterapkan untuk mereduksi jumlah ciri yang digunakan dalam fase pelatihan JST

\section{UCAPAN TERIMA KASIH}

Penulis mengucapkan terima kasih kepada database MESSIDOR yang telah memberikan dukungan data citra retinopati diabetes beserta data hasil pemeriksaan medis terhadap penelitian ini.

\section{DAFTAR PUSTAKA}

[1] Fadzil,A., M., H., Izhar, L., I., Nugroho, H., Nugroho, H., A., 2011, Analysis of Retinal Fundus Images for Grading of Diabetic Retinopathy Severity, Med. Biol. Eng.Comput, 49,693-700.

[2] Kuivaleinen, M., 2005, Retinal Image Analysis Using Machine Vision, Tesis, Departemen of Information Technology, Lappeenranta University of Technology, Lappeenranta. 
[3] Sopharak, A., Dailey,M., N., Uyyanonvara, B., Barman, S., Williamson, T., New, K., T., Moe, Y., A., 2010, Machine Learning Approach to Automatic Exudate Detection in Retinal Images from Diabetic Patients, Journal of Modern Optic, No. 2, Vol. 57, 124-135.

[4] David, J., Krihnan, R., Kumar, S., 2008, Neural Network Based retinal Image Analysis, IEEE.

[5] Prabakar, S., Porkumaran, K., Shah, P., K., Narendran, V., 2011, A Novel Image Processing Approach for Retinopathy of Prematurity Stage Screening, European Journal of Scientific Research, No. 3, Vol. 55, 334 - 347.

[6] Ulinuha, M., Purnama, I., Hariadi, M., 2010, Segmentasi Optic Disc pada Penderita Diabetic Retinopathy Menggunakan GVF Snake.

[7] Gadkari, D., 2004, Image Quality Analysis Using GLCM, Tesis, University of Central Florida, Florida.

[8] Gonzales, R., C., Woods, R., E., 2008, Digital Image Processing, $3^{\text {rd }}$ ed., Prentice Hall : Upper Sadle River, NewJersey, USA.

[9] Priya, R., Aruna, P., 2010, Review of Automated Diagnosis Of Diabetic Retinopathy using The Support Vector Machine, International Journal of Applied Engineering Research, No. 4, Vol. 1, 844-863. 